$\xi_{p}$

\title{
Flood and Flash Flood Geo-Hazards in Malaysia
}

\author{
F. S. Buslima ${ }^{1}$, R. C. Omar ${ }^{1}$, Tajul Anuar Jamaluddin ${ }^{2}$, Hairin Taha ${ }^{1}$ \\ ${ }^{1}$ Forensic Engineering Group, Institute of Energy Infrastructure, Universiti Tenaga Nasional \\ ${ }^{2}$ Geology Programme, Faculty of Science \& Technology, National University of Malaysia \\ *Corresponding author E-mail: Faten@uniten.edu.my
}

\begin{abstract}
Floods are natural phenomena of geo-hazards that usually happened when experiencing prolonged heavy rainfalls. Floods in Malaysia can be categorized into monsoon floods and flash floods. Monsoon floods is caused of Northeast Monsoon season commences in early November and ends in March that brings heavy rainfall, particularly to the east coast states of Peninsular Malaysia and western Sarawak. Flash floods usually occur in areas with rapid development by a rapid rise in water level, high velocity, and large amounts of debris. Flooding that occurred in December 2014 can be classified as worst floods that affected several states in Peninsular Malaysia, and the worst affected is Kelantan state. This disaster was recorded more than 200,000 people were affected with 21 people were killed and gives a massive impact on people, properties, agriculture, livestock, and infrastructure facilities. Following the worst floods that hit Malaysia in 2014, the opinions and views from various parties such as subject matter experts was needed to produce mitigations and prevents of the flood disaster at once to minimize vulnerability to hazard.
\end{abstract}

Keywords: Flood; Flash Flood; Flood Implication; Kelantan; Mitigation Plan

\section{Introduction}

Geo-hazards are natural phenomena that typically triggering the natural disasters cause fatalities, damages, and severe impacts to social and economic. Hazard is an event or physical condition that has the potential to cause fatalities, injuries, property damage, agricultural loss, damage to environment, interruption of business, or other types of harm or loss [1]. These natural disasters consist of landslide, earthquake, tsunami, flood and others. Flooding is hydrologic hazards that occur naturally triggered by heavy rainfall.

Hazards associated with flooding can be divided into primary hazards, secondary hazards and tertiary hazards or long term hazards [2]. The primary hazards are effects of floods due to direct contact with the flood waters. With high velocities, streams are able to transport larger particles as suspended load. These large particles can include not only rocks and sediment, but during the flood, could include such large objects as automobiles, houses and bridges. The secondary hazards are that occur because of the primary hazards (flooding), such as disruption of services and health impacts (famine and disease).The tertiary hazards are long term changes such as changes in the position of river channels.

The purpose of this paper is to briefly outline the flood scenario in Malaysia especially the flood disaster in 2014 is said to be the worst event ever experienced in Kelantan and Terengganu as well as its implications of the floods in aspect of social, economic and infrastructure. These issues followed by flood disaster managements to overcome the impacts of flooding with five activity areas, namely prevention, preparedness, response, recovery and governance.

\section{Flood and Flash Flood}

Flooding is defined as the accumulation of water within a water body and the overflow of excess water onto adjacent floodplain land. The floodplain is the land adjoining the channel of a river, stream, ocean, lake or other watercourse or water body that is susceptible to flooding [1]. Floods in Malaysia can be categorized into monsoon floods and flash floods. Rainfall distribution patterns in Malaysia are influenced by the seasonal wind flow patterns and the local topographic features. Malaysia experienced the Northeast Monsoon season commences in early November and ends in March. Figure 1 shows the rainfall patterns that influenced by the Northeast Monsoon brings heavy rainfall and causes floods, particularly to the east coast states of Peninsular Malaysia and western Sarawak.

Flash floods usually occur in areas with rapid development. Flash floods are characterized by a rapid rise in water level, high velocity, and large amounts of debris. Flash floods are cause by factors the intensity and duration of rainfall as well as the steepness of watershed and stream gradients. Flash flooding in urban areas is an increasingly serious problem due to removal of vegetation, paving and replacement of ground cover by impermeable surfaces that increase runoff, and construction of drainage systems that increase the speed of runoff [1].

Based on the hydrological perspectives, a difference between flood and flash flood is the period taken by river flow to recede back to the normal level [4]. Flood (or monsoon floods) takes a long term and may last a week or more to return to the normal water flow level, whereas, flash flood takes only few hours. National Oceanic and Atmospheric Administration, NOAA stated that flash floods occur within a few minutes or hours of excessive rainfall and most of events followed by slow-moving thunderstorms, thunderstorms repeatedly moving over the same area, or 
heavy rains from hurricanes and tropical storms [5]. Flash floods are events of short duration with a relatively high peak discharge and tend to occur frequently but at a very small scale [6].

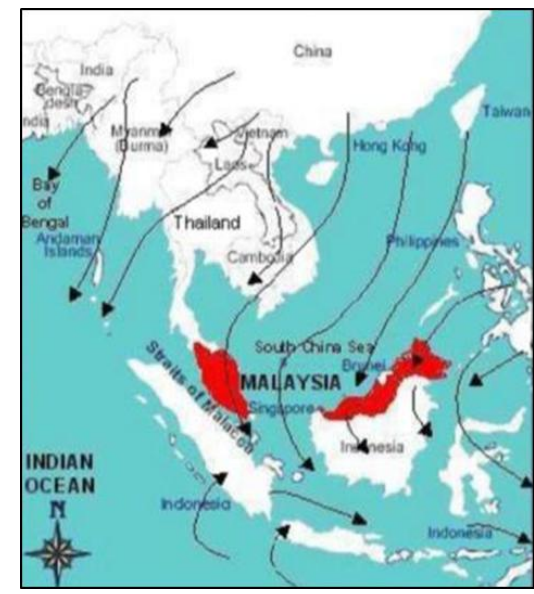

Fig. 1: Rainfall patterns that influenced by the Northeast Monsoon [3]

\section{History of Flood in Malaysia}

Floods and flash floods in Malaysia often happen when experiencing prolonged heavy rainfalls. Flooding during the monsoon season often experienced in the east coast states of Peninsular Malaysia such as Kelantan, Terengganu and Pahang and Western Sarawak. According to Malaysian Medical Relief Society, MERCY, rapid urbanization of floodplains such as those in Kuala Lumpur, Penang and Sarawak, and upstream development of hill land have rendered many areas vulnerable to hazardous flash floods [7] Historically, there have been big flood events in 1886, 1926, 1931, 1947, 1954, 1957, 1965, 1967, 1970/1971, 1988, 1993, 1996, 2000, 2006/2007, 2008, 2009, and 2010 [8]. Kuala Lumpur was hit by major flash floods in 1971 as several riverbanks broke due to heavy monsoon rains. This event affected more than 180,000 evacuees with 32 fatalities [7]. The latest of worst flood in Malaysia is happened on December 2014 has been the worst floods in decades. Table 1 shows a summary of the history of floods and flash floods that occurred in Malaysia form 1996 until 2016.

Table 1: Flooding History in Malaysia

\begin{tabular}{|c|c|c|c|}
\hline No. & Year & Floods Incidence & The effects of disasters \\
\hline 1 & $1996[8]$ & $\begin{array}{l}\text { Floods brought by } \\
\text { Tropical Strorm Greg } \\
\text { in Keningau, Sabah }\end{array}$ & $\begin{array}{l}\text { - } 241 \text { people were killed } \\
\text { - Estimated more than USD } \\
97.8 \text { million damage to } \\
\text { infrastructure and prop- } \\
\text { erty } \\
\text { - Destroyed thousands of } \\
\text { houses }\end{array}$ \\
\hline 2 & $2000[8]$ & $\begin{array}{c}\text { Floods caused by } \\
\text { heavy rainfall in } \\
\text { Kelantan, Terengganu } \\
\text { and northern Peninsu- } \\
\text { lar Malaysia } \\
\end{array}$ & $\begin{array}{l}\text { - } 15 \text { people were killed in } \\
\text { Kelantan and Terengganu } \\
\text { - More than } 10,000 \text { evacu- } \\
\text { ees affected in northern } \\
\text { Peninsular Malaysia }\end{array}$ \\
\hline 3 & $2001[9]$ & $\begin{array}{l}\text { Floods brought by } \\
\text { Tropical Storm } \\
\text { Vamei in eastern } \\
\text { Malaysia }\end{array}$ & $\begin{array}{l}\text { - Storm causes flooding } \\
\text { and landslide in eastern } \\
\text { Malaysia } \\
\text { - Five people were killed } \\
\text { - Estimated USD } 3.6 \text { mil- } \\
\text { lion damage } \\
\end{array}$ \\
\hline 4 & $\begin{array}{c}\text { April \& } \\
\text { Oct } 2002 \\
{[10]}\end{array}$ & Flash Flood & $\begin{array}{l}\text { - Flash flood that affected } \\
\text { Kuala Lumpur }\end{array}$ \\
\hline 5 & $\begin{array}{c}\text { Oct } 2003 \\
{[10]}\end{array}$ & $\begin{array}{l}\text { Flood in the north- } \\
\text { western Peninsular } \\
\text { Malaysia }\end{array}$ & $\begin{array}{l}\text { Flood that affected a large } \\
\text { area in the northwestern } \\
\text { Peninsular Malaysia cov- } \\
\text { ering states of Kedah, } \\
\text { Penang and northern } \\
\text { Perak }\end{array}$ \\
\hline
\end{tabular}

\begin{tabular}{|c|c|c|c|}
\hline 6 & $\begin{array}{l}\text { Dec } 2006 \\
\quad \& \text { Jan } \\
2007[8]\end{array}$ & Flood in Johor & $\begin{array}{l}\text { - } 18 \text { people were killed } \\
\text { - Estimated USD } 489 \text { mil- } \\
\text { lion in damage }\end{array}$ \\
\hline 7 & $\begin{array}{c}2008 \\
{[8]}\end{array}$ & Flood in Johor & $\begin{array}{l}\text { - } 28 \text { people were killed } \\
\text { - Estimated USD } 21.19 \\
\text { million damage }\end{array}$ \\
\hline 8 & 2010 [8] & $\begin{array}{l}\text { Flood in Kedah and } \\
\text { Perlis }\end{array}$ & $\begin{array}{l}\text { - four people were killed } \\
\text { - Estimated 45,000 hectares } \\
\text { of paddy fields were de- } \\
\text { stroyed } \\
\text { - More than 50,000 evacu- } \\
\text { ees affected in Kedah }\end{array}$ \\
\hline 9 & $\begin{array}{c}2013 \\
{[11]}\end{array}$ & $\begin{array}{l}\text { Flash Flood in Cam- } \\
\text { eron Highlands }\end{array}$ & $\begin{array}{l}\text { - Flash flood caused by the } \\
\text { water released from Sul- } \\
\text { tan Abu Bakar dam } \\
\text { - Three people were killed } \\
\text { - } 80 \text { houses affected and } \\
100 \text { vehicles damaged }\end{array}$ \\
\hline 10 & $\begin{array}{l}\text { Dec } 2014 \\
\text { \& Jan } \\
2015 \\
{[12]}\end{array}$ & $\begin{array}{c}\text { Flood in Peninsular } \\
\text { Malaysia }\end{array}$ & $\begin{array}{l}\text { - Several states in Peninsu- } \\
\text { lar Malaysia were af- } \\
\text { fected; Kelantan, Tereng- } \\
\text { ganu, Pahang, Perak, Sa- } \\
\text { bah, Negeri Sembilan, } \\
\text { Johor, Perlis, Kedah and } \\
\text { Sarawak } \\
\text { - More than 200,000 peo- } \\
\text { ple were affected with } 21 \\
\text { people were killed } \\
\text { - Estimated more than RM } \\
\text { 1 Billion damage } \\
\end{array}$ \\
\hline 11 & $\begin{array}{c}\text { May } \\
2016 \\
{[13][14]}\end{array}$ & $\begin{array}{l}\text { Flash Flood in Kuala } \\
\text { Lumpur and Selangor }\end{array}$ & $\begin{array}{l}\text { Flash flood that affected } \\
\text { four main roads in Kuala } \\
\text { Lumpur } \\
\text { - } 15 \text { cars were submerged } \\
\text { and hundreds more were } \\
\text { trapped in Kuala Lumpur } \\
\text { - More than } 300 \text { evacuees } \\
\text { affected at Dengkil, Se- } \\
\text { langor }\end{array}$ \\
\hline
\end{tabular}

\subsection{Review of 2014 Malaysia Flood}

The history of worst flooding were recorded in 1967, where heavy monsoon rains that have hit the state in east coast of Peninsular Malaysia especially Kelantan and Terengganu as well as some states in West Malaysia such as Perak, Pahang, Kedah, Perlis, Johor and some places in Penang. This event led to more than 250,000 people in urban and rural areas have been affected by floods recorded as the biggest flood to destroy the West Malaysia [15]. Flooding that occurred in December 2014 can also be classified as worst same as the floods in 1967. Several states were affected namely Kelantan, Terengganu, Pahang, Perak, Negeri Sembilan, Johor, Perlis and Kedah as well as Sabah and Sarawak.

The flood disaster in 2014 is said to be the biggest event ever experienced. Especially in Kelantan, the flood area affected includes the districts of Kota Bharu, Machang, Pasir Mas, Pasir Puteh, Tanah Merah, Gua Musang and Tumpat. District of Kuala Krai is areas badly hit by the floods especially Manik Urai and Dabong. This state suffers from two phase of flood. The first phase began on December $14-17,2014$, and the second phase occurred on December 20 - 24, 2014. The incident occurred due to non-stop of extreme rainfall for several days.

The recorded rainfall from telemetry station at Kelantan shows that the highest amount of rainfall is during December $15-25$, 2015 [16]. The highest value for duration 10 days is at Gunung Gagau Station about $1898 \mathrm{~mm}$, while the lowest value of accumulated rainfall during the flood event is at Lojing station about 476 $\mathrm{mm}$. This causes the water level at Kelantan watershed are highest recorded in comparison with previous decades and most of the parts of Kelantan watershed are involved with over danger values for flood in 2014, which Lebir and Kelantan rivers have high increasing. Figure 2 shows the residential areas and shop buildings 
were flooded at Bandar Baru Tanah Merah. The water level rises above the critical level causing the surrounding area suffered severe flooding.

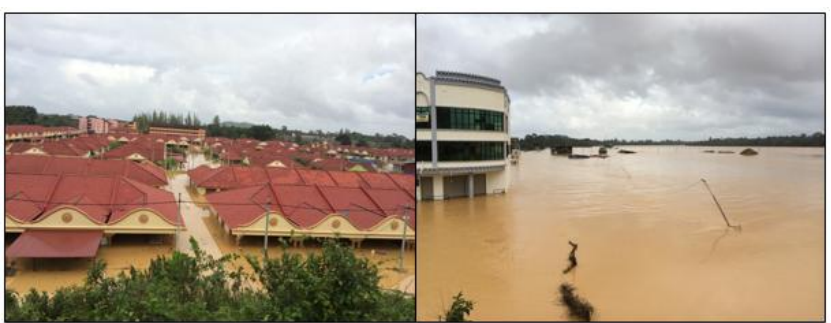

Fig. 2: Flood disaster in Tanah Merah, Kelantan

Ibrahim Komoo [17] states that the impact of floods in Sungai Galas and Sungai Lebir for example had increased the content of mud, silt and debris as shown in Figure 3. Figure 4 shows the debris that consists of timber and plant debris was destroying of various infrastructures, including bridges and settlement.

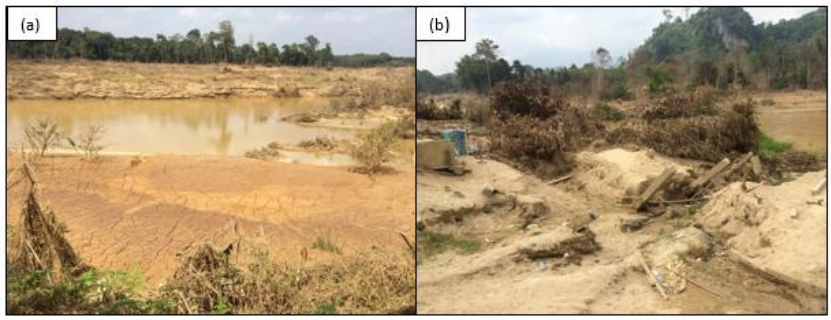

Fig. 3: Increasing of mud, silt and debris at (a) Sungai Galas and (b) Sungai Lebir

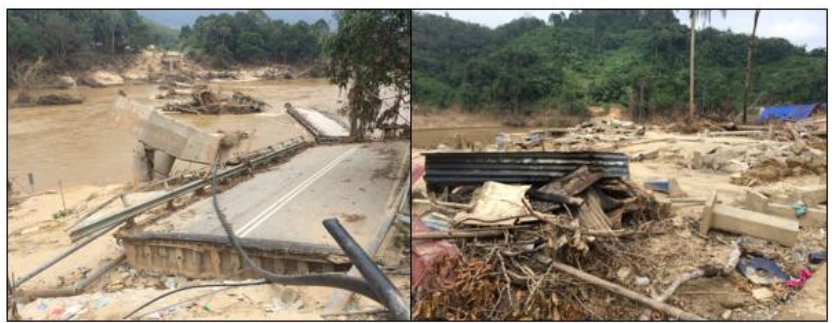

Fig. 4: Impact of 2014 flood causes various infrastructures destroyed

In Terengganu, the first wave of floods occurred in November 2014 when the high rainfall for over a week in Kuala Terengganu and around causes the surface of the soil becomes saturated and the groundwater level increases. This causes the whole of low areas were flooded. When the ground water level continues to rise and there is no good drainage system to channel water to the sea, causing the road becomes a temporary drainage system and affect the development area by the flooding phenomenon [18]. Then followed by a second wave of floods occur at the end of 2014. The worst affected district in Terengganu is Kemaman, followed by Dungun, Kuala Terengganu, Hulu Terengganu, Besut and Marang. Figure 5 shows the flood that has submerged the first floor of the school building and the residents using speedboat to carry out their daily activities in Hulu Terengganu.

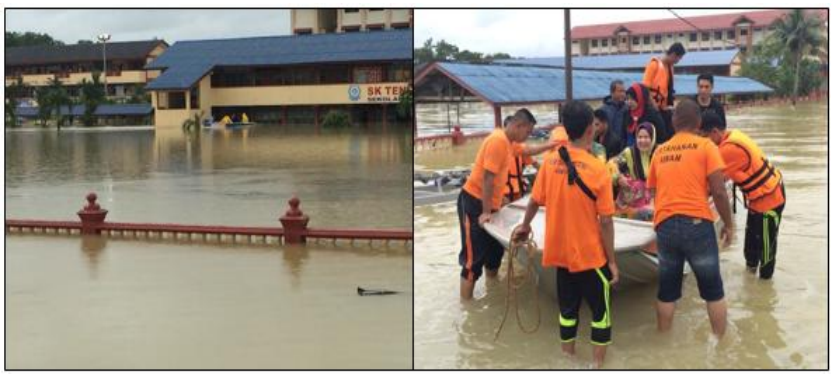

Figure 5: Flood disaster in Hulu Terengganu, Terengganu
Overall, a flood in 2014 was recorded of 232, 913 evacuees were registered in various evacuation centers across Peninsular Malaysia [7]. However, the actual number of those affected is believed to be higher as numerous people were unable to reach evacuation centers and several evacuation centers were unregistered. This event gives a massive impact on people, properties, agriculture, livestock, and infrastructure facilities such as roads, railroads, electricity, telephone, water and food supply. This disaster also caused adverse effects on the mental and physical health of the evacuees.

\section{Flood Implications}

Flood hazards give a negative impacts that caused fatalities, damages, and severe impacts to social and economic. Impacts of flood hazards include structural damage and erosion, loss of property, food and water pollution, disturbance of socio-economic activities such as transport and communications, as well as damage to agricultural land [19]. The impact of disasters are divided into physical impacts and social impacts [20]. The physical impacts include casualties (deaths and injuries) and properties damage. This section describes the flood implications in social, economic, and infrastructure.

\subsection{Social Impacts of Flood}

The social impact involves four aspects, namely psychosocial, socio-demographic, socio-economic and socio-political [20]. Psychosocial impacts are referring to mental health of the flood disaster victims. It is include emotional signs such as anxiety, depression and grief as well as behavioural effects. Socio-demographic impacts can be seen in the management of residential and resettlement to flood victims. People typically pass through four stage of housing recovery when experiencing a disaster [21]. These stages are emergency shelter, temporary shelter, and followed by temporary housing and permanent housing. For the victims, this is a very painful impression because they had to stay in shelters and tents provided in a long time to get temporary or permanent housing.

The most effect was felt after a disaster is the socio-economic impacts involving the loss of properties causes a reduction in consumption and decrease in the quality of life [20]. Although there are replacement of assets or goods by donations or buying later, it cannot be replace lost properties before where it would be perceived as a loss. It is becoming more difficult for communities who do not have insurances, their lives are absolutely no guarantees and the process of rebuilding what was lost will be a restraint when influenced by age, mental health and dependency [22]. The socio-political impacts is refers in the period of recovery from disaster. This effect can be seen when there is a change in the political behaviour of politician will be more aggressive to get the attention of people who are involved and often lead to more intense political feud. The situation will become more disordered when local politicians intervene and worsen the situation.

Apart of the elements mentioned above, flooding also cause the impact in education. During floods, schools serve as an evacuation centers and there are also schools that were flooded. Following that, opening for all primary and secondary schools was delayed by one week because carry out cleaning works to ensure that all schools are clean and safe for the students before the opening day [23].

\subsection{Economic Impacts of Floods}

Flood disaster affects the economy either in the short or long time and its impact is difficult to measure accurately because it not only involves the value of the currency, but it also includes perceptions and emotions of those involved also people who see it [24]. Destruction of crops and livestock during the floods give the big 
impact to economic. Farmers and breeders would lose a source of income for several months until the crops or livestock can be recovered. Vegetables and fruits plants almost $100 \%$ destroyed and rubber trees experienced wintering before it's time [25]. Palm trees can survive with the water reservoir, but productivity may decline during the harvest.

Floods also have its impacts on tourism, not only direct and indirect losses as well as damages to the premises and touristic attractions. The immediate impacts can be clearly seen in sub-sectors of tourism especially among tour agencies, hotel sector, shopping, heritage sites and retailers. The performance of tourism industry had decline due to the obstacles and risks caused by the floods [26].

\subsection{Infrastructure Impacts of Floods}

Infrastructure is a facilities or basic services such as transportation, health, electricity and water supply to develop a community. Impacts of infrastructure that often happen when the flooding, whether flash floods and monsoon floods is a closure of several roads at lower areas. Vehicles passing through the area at risk of flooding may be vulnerable to the problem of vehicles flooded or caught in the flooding. This situation will lead to extraordinary congestion and takes long hours.

Floods in December 2014 left a high impact on infrastructure in Kelantan. This event causes closure of several roads, which is 26 of Federal roads and 35 of State roads [27]. Federal roads were also closed due to landslides, in which these events have the same factor, caused by high rainfall that hit of Kelantan in December 2014. Figure 6 shows the Federal road that link of East West Peninsular Malaysia, from Jeli to Gerik, Perak collapsed at Kilometer (KM) 66 on December 23, 2014 and it's closed to traffic [28]. There are also bridges which were destroyed due to strong currents and several other bridges had to be closed for safety reasons. Keretapi Tanah Melayu (KTM) has canceled all trains on the East Coast Peninsular Malaysia for the safety of passengers. This is due to the 50 meters railway bridge in Kemubu - Dabong was flooded and damage to the runway as well as there are also some stations collapsed and flooded.

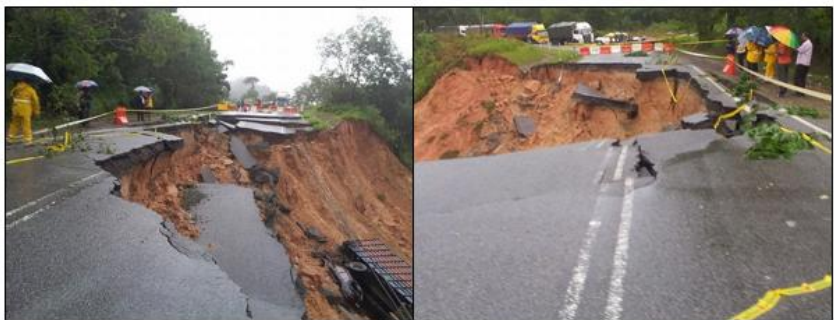

Fig. 6: Closure Federal road, from Jeli to Gerik caused by Landslide [29]

During a flood, the health of those affected has to be prioritized. Dirty flood waters and lack of sufficient hygiene facilities pose a serious risk for the spread of infections and waterborne diseases. The most common diseases that occur during flood are fungal infections, fever, flu, diarrhoea and cough [7]. Utilities such as electricity, water supply and communication lines were badly affected during the floods of 2014. Almost all districts in Kelantan experienced this effect for 11 days starting on December 17-28, 2014 [30].

\section{Flood Disaster Management}

Disaster management is a plan that should be focused in order to communities in order to reduce the vulnerability to hazards and copes with disasters. According to International Federation of Red Cross and Red Crescent Societies (IFRC) [31], disaster management can be defined as the organization and human resources management that responsibilities for dealing with all humanitarian aspects of emergencies, in particular preparedness, response and recovery in order to lessen the impact of disasters. The main mission of flood disaster management is to minimize vulnerability to floods and consequent loss of lives, livelihood systems, properties and damage to infrastructure and public utilities [32].

Referring to Kamarulazizi Ibrahim et al. [33], flood disaster management consists of five activity areas namely prevention, preparedness, response, recovery and governance. These five activity areas are referred to the flood events that occur either before, during or after the incident. Table 2 shows the suggested mitigation plans under the five activity areas to overcome the impacts of flooding.

Table 1: Mitigation Plans in Flood Disaster Management [33]

\begin{tabular}{|c|c|c|}
\hline No & Activity Area & Mitigation Plan with Responsible Agency \\
\hline 1. & Prevention & $\begin{array}{l}\text { i. Sustain and improve the drainage system } \\
\text { - Department of Irrigation and Drainage } \\
\text { ii. Identify high risk areas as a collection point } \\
\text { during an emergency } \\
\text { - Malaysian National Security, Local Au- } \\
\text { thorities, Volunteers Department Malaysia } \\
\text { (RELA), Non-Governmental Organization, } \\
\text { Malaysian Armed Forces, Ministry of Ru- } \\
\text { ral and Regional Development } \\
\text { iii. Prepare profiling and bank data for margin- } \\
\text { alized community } \\
\text { - Head of villages, community leader, So- } \\
\text { cial Department of Social Welfare, Jabatan } \\
\text { Kemajuan Orang Asli and Security Com- } \\
\text { munity }\end{array}$ \\
\hline 2. & Preparedness & $\begin{array}{l}\text { i. Make sure the availability of stand-alone } \\
\text { electrical generator at appropriate location } \\
\text { enough to meet the needs and with ade- } \\
\text { quate power capacities } \\
\text { - State Disaster Committee, Tenaga Na- } \\
\text { sional Berhad } \\
\text { ii. Upgrade the telemetric system to get real } \\
\text { time data and linking them to central facili- } \\
\text { ties for real time flood forecasting } \\
\text { - Department of Irrigation and Drainage, } \\
\text { Federal Development Department and, } \\
\text { State Government, National Security } \\
\text { Council } \\
\text { iii. Conduct water sampling and early warning } \\
\text { system at permanent sampling sites to } \\
\text { monitor water quality } \\
\text { - Department of Environment }\end{array}$ \\
\hline 3. & Response & $\begin{array}{l}\text { i. Provide a system with better information } \\
\text { sharing between agencies involved } \\
\text { - Department of Social Welfare, Depart- } \\
\text { ment of the Prime Minister, Secretary State } \\
\text { Office (SUK), Ministry of Communications } \\
\text { \& Multimedia, Meteorology Department } \\
\text { and Malaysian Administrative Moderniza- } \\
\text { tion and Management Planning Unit } \\
\text { (MAMPU) } \\
\text { ii. Establish the nearest health teams to carry } \\
\text { out investigations and control of epidemics } \\
\text { in the affected areas } \\
\text { - Malaysian National Security Council, } \\
\text { District officers, Ministry Of Finance, Min- } \\
\text { istry Of Health, Ministry of Education, De- } \\
\text { partment of Social Welfare, Public Works } \\
\text { Department, Department of Irrigation and } \\
\text { Drainage, Tenaga Nasional Berhad and Air } \\
\text { Kelantan Sdn. Bhd. } \\
\text { iii. Monitor road safety and the slope of the } \\
\text { hill side of the road because feared land- } \\
\text { slides } \\
\text { - Public Works Department }\end{array}$ \\
\hline 4. & Recovery & $\begin{array}{l}\text { i. Implement reforestation on all degraded } \\
\text { land based on international standards for } \\
\text { erosion control and sedimentation } \\
\text { - All agencies involved, State Secretary, } \\
\text { Economic Planning Unit, Forestry Depart- } \\
\text { ment, Ministry of Natural Resources and } \\
\text { Environment, Department of Irrigation and }\end{array}$ \\
\hline
\end{tabular}




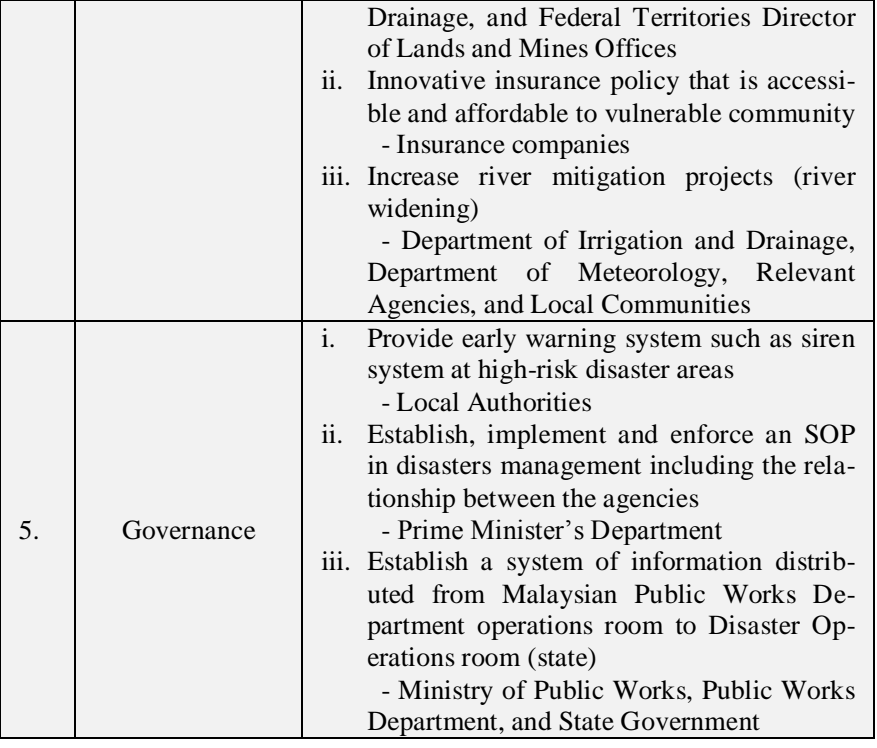

\section{Conclusion}

Flooding is a phenomenon that affects many individuals and around either mental or physical. Floods can also destroy assets and properties as well as cause a massive loss. The following the worst floods that hit Malaysia in 2014, the various parties together to discuss the issues and find a solution to manage floods disaster in the future. Opinions and views from various parties such as subject matter experts from various organizations, agencies and institutions of government and non-governmental organizations, as well as academia and the victims needed to produce mitigations and prevents of the flood disaster. Actions by all parties will develop resistance to residents thereby improving the standard of living of the population affected by the floods.

\section{Acknowledgement}

The examples of photographs presented in this paper are a part of the activities in project "Research and Development for reducing Geo-Hazard Damage in Malaysia in caused by Landslide and Flood". The author would like to convey her gratitude to Forensic Engineering Group, Institute of Energy Infrastructure for the opportunity to be one of the team members in this project that funded by Ministry of Higher Education Malaysia (MOHE) and Japan International Cooperation Agency (JICA) [01201307LRGS].

\section{References}

[1] Federal Emergency Management Agency (FEMA). 1997. Multihazard identification and risk assessment: a cornerstone of the national mitigation strategy. United States of America: Federal Emergency Management Agency.

[2] Nelson, S. A. 2015. Flooding hazards, prediction \& human intervention.http://www.tulane.edu/ sanelson/Natural_Disasters/floodhaz.htm [6 May 2016].

[3] Sani G. D/iya, Muhd Barzani Gasim, Mohd Ekhwan Toriman \& Musa G. Abdullahi. 2014. Floods in Malaysia: historical reviews, causes, effects and mitigation approach. International Journal of Interdisciplinary Research and Innovation 2: 59-65.

[4] Noorazuan Md. Hashim. 2006. Urban hydrological changes in the Sankey Brook catchment. PhD thesis University of Manchester.

[5] NOAA. 1992. Flash floods and floods the awesome power: a preparedness guide. United State: National Oceanic and Atmospheric Administration.

[6] World Meteorological Organization. 2007. Global approach to address flash floods, in MeteoWorld. http://www.hrclab.org/publicbenefit/downloads/wmo-flashflood.pdf [10 May 2016].

[7] MERCY. 2014. Malaysian flood emergency response donor report 2014: December 2014. Malaysia: Malaysian Medical Relief Society.
[8] Ngai Weng Chan. 2012. Impacts of disasters risk management in Malaysia: The case of floods. In Sawada, Y. \& S. Oum (eds.). Economic and welfare impacts of disasters in East Asia and policy responses, pp. 503-551. Jakarta: ERIA.

[9] Alui Bahari. 2012. The usage of weather information in decision making.. Slaid. Taiwan: APEC Research Center for Typhoon and Society.

[10] Abd. Jalil Hassan, Aminuddin Abd. Ghani \& Rozi Abdullah. 2006. Development of flood risk map using GIS for Sg. Selangor Basin. http://www.redac.eng.usm.my.html [10 May 2016].

[11] Manjit Kaur. 2013. Three killed in mud flood after water released from Cameron Highland dam. http://www.thestar.com.my/news/nation/2013/10/23/cameronhighlandda $\mathrm{m} /[10$ May 2016].

[12] Zainal Abidin Akasah \& Sunitha V. Doraisamy. 2015. 2014 Malaysia flood: impacts \& factors contributing towards the restoration of damages. Journal of Scientific Research and Development 2: 53-59

[13] BERNAMA. 2016. Lebih 300 mangsa banjir di Dengkil dipindahkan. http://www.bharian.com.my/node/151708 [11 May 2016].

[14] Nor Azizah Mokhtar. 2016. Ratusan kereta terperangkap, jalan sesak akibat banjir kilat. http://www.bharian.com.my/node/153012 [11 May 2016].

[15] Noor Syamimi Ishak, Azharudin Mohamed Dali \& Mohamad Rodzi Abdul Razak. 2014. Sejarah banjir besar di Semenanjung Malaysia, 1926-1971. Jurnal Perspektif 3:54-67.

[16] Aminah Shakirah Jaafar, Lariyah Mohd Sidek, Hidayah Basri, Nazirul Mubin Zahari, Milad Jajarmizadeh, Hanapi Mohamad Noor, Sazali Osman, Abdul Hafiz Mohammad and Wan Hazdy Azad. 2015. An Overview: Flood Catastrophe of Kelantan Watershed in 2014. Proceedings of the International symposium on flood research and management 2015 , pp. 17-29.

[17] Ibrahim Komoo. 2015a. Bencana banjir besar 2014 https://ibrahimkomoo.com/2015/05/21/bencana-banjir-besar-2014/ [24 May 2016].

[18] Ibrahim Komoo. 2015b. Fenomena banjir Terengganu 2014. https://ibrahimkomoo.com/2015/05/20/ fenomena-banjir-terengganu2014/ [24 May 2016].

[19] Marvin, D. 1969. Flood plain management. Iowa: Iowa University Press.

[20] Lindell, M. K and Prater, C. S. 2003. Assessing community impacts of natural disasters. Natural Hazards Review ASCE. November: 176-185.

[21] Quarantelli, E. L. 1982. Sheltering and housing after major community disaster: case studies and general conclusions. Newark, Delaware: University of Delaware Disaster Research Center.

[22] Faisal Tehrani. 2015. Impak sosial setelah banjir di Kelantan. http://www.projekdialog.com/featured/ impak-sosial-setelah-banjir-dikelantan/ [25 May 2016].

[23] BERNAMA. 2014. Schools to open one week later due to massive floodshttp://www.themalaymailonline.com/malaysia/article/schools-toopen-one-week-later-due-to-massive-floods [24 May 2016].

[24] Faisal Hamidi. 2011. Kesan bencana alam kepada ekonomi Negara. http://ww1.utusan.com.my/utusan [25 May 2016].

[25] Anim Hosnan. 2014. Banjir: kesan sektor pertanian. http://animhosnan.blogspot.my/2014/12/banjir-kesan-sektorpertanian.html [25 May 2016].

[26] J. Hamzah, A. Habibah, A.Buang, K. Jusoff, M. E. Toriman, M. J. Mohd Fuad, A. C. Er \& A. M. Azima. 2012. Flood disaster, impacts and the tourism providers' responses: the Kota Tinggi experience. Advance in Natural and Applied Sciences 6(1): 26-32

[27] Roslan Md. Taha. 2015. Persidangan pengurusan bencana banjir Kelan$\tan$ 2015. Slaid. Pulau Pinang: Centre for Global Sustainability Studies (CGSS) USM

[28] Utusan Online. 2014. Laluan timur barat Jeli-Gerik runtuh http://www.utusan.com.my/berita/nahas-bencana/laluan-timur-baratjeli-gerik-runtuh-1.40092 [24 May 2014].

[29] BERNAMA. 2015. Laluan Gerik ke Jeli dibuka 12 tengah hari tadi. http://www.mynewshub.cc /2015/01/05/laluan-gerik-ke-jeli-dibuka-12tengah-hari-tadi/ [24 May 2016].

[30] Tengku Mohamed Faziharudean Tengku Feissal. 2015. Pembangunan dan pengurusan di kawasan terdedah banjir. Slaid. Pulau Pinang: Centre for Global Sustainability Studies (CGSS) USM.

[31] Federation of Red Cross and Red Crescent Societies (IFRC). t.th. About disaster management. http://www.ifrc.org/en/what-we-do/disastermanagement/about-disaster-management/[26 May 2016]

[32] National Disaster Management Authority of India. 2008. National disaster management guidelines: management of floods. India: National Disaster Management Authority of India.

[33] Kamarulazizi Ibrahim, Kanayathu Chacko Koshy, Noor Adelyna Mohammed Akib, Radieah Mohd Nor, Normaliza Abdul Manaf, Sharifah Nurlaili Farhana Syed Azhar \& Marlinah Muslim. 2015. Resolution: Kelantan flood disaster management conference 2015. Pulau Pinang: Centre for Global Sustainability Studies (CGSS) USM 